\title{
Multivariate statistical analysis of heavy metals in foliage dust near pedestrian bridges in Guangzhou, South China in 2009
}

\author{
Yanming Zheng $\cdot$ Quanzhou Gao $\cdot$ Xiaohao Wen • \\ Ming Yang • Haidong Chen $\cdot$ Zhaoqiang Wu • \\ Xiaohong Lin
}

Received: 26 February 2012/ Accepted: 30 October 2012/Published online: 18 November 2012

(C) The Author(s) 2012. This article is published with open access at Springerlink.com

\begin{abstract}
The heavy metal content of particulate matter was investigated in the city of Guangzhou in southern China. Samples of urban foliage near 36 pedestrian bridges were analyzed to determine their $\mathrm{Zn}, \mathrm{Pb}, \mathrm{Cu}, \mathrm{Cr}, \mathrm{V}, \mathrm{Ni}$, and $\mathrm{Co}$ contents after digestion in a mixture of strong acids composed of $\mathrm{HNO}_{3}, \mathrm{HCl}, \mathrm{HF}$, and $\mathrm{HClO}_{4}$. The results revealed a severe heavy metal pollution compared with the background levels in Chinese soils, except for Co and V. The mean concentrations of $\mathrm{Zn}\left(1,024 \mathrm{mg} \mathrm{kg}^{-1}\right), \mathrm{Pb}\left(233 \mathrm{mg} \mathrm{kg}^{-1}\right)$, $\mathrm{Cu}\left(203 \mathrm{mg} \mathrm{kg}^{-1}\right), \mathrm{Cr}\left(118 \mathrm{mg} \mathrm{kg}^{-1}\right), \mathrm{V}\left(41.9 \mathrm{mg} \mathrm{kg}^{-1}\right)$, $\mathrm{Ni}\left(41.4 \mathrm{mg} \mathrm{kg}^{-1}\right)$, and Co $\left(11.3 \mathrm{mg} \mathrm{kg}^{-1}\right)$ in urban dust were higher than the reference levels, and were highest in samples located near high-traffic areas. Multivariate statistical methods (correlation analysis, principal-components analysis, and clustering analysis) were used to identify the possible sources of the metals. Three main pollutant sources are assigned: $\mathrm{Zn}, \mathrm{Cu}$ and $\mathrm{Ni}$ levels were strongly correlated
\end{abstract}

Electronic supplementary material The online version of this article (doi:10.1007/s12665-012-2107-z) contains supplementary material, which is available to authorized users.

\section{Y. Zheng $(\bowtie) \cdot$ Q. Gao}

School of Geography and Planning and Guangdong Provincial

Key Laboratory for Urbanization and Geo-simulation,

Sun Yat-sen University, 510275 Guangzhou,

People's Republic of China

e-mail: nhzym2@163.com

\section{Y. Zheng}

MOE Engineering Center of Desertification and Blown-sand Control, Beijing Normal University, 100875 Beijing, People's Republic of China

X. Wen $\cdot$ M. Yang $\cdot$ H. Chen $\cdot$ Z. Wu $\cdot$ X. Lin School of Geographical Science, South China Normal University, 510631 Guangzhou, People's Republic of China and were possibly related to combustion processes and vehicles; $\mathrm{Pb}, \mathrm{Cr}$ and $\mathrm{Co}$ were mainly derived from traffic sources, combined with soil sources; and V mainly originated from natural sources.

Keywords Dusts - Heavy metals · Particulate matter . Pedestrian Bridges · Guangzhou

\section{Introduction}

With the rapid pace of global industrialization and urbanization, particularly in megalopolises, urban environmental problems, and especially the degradation of urban air quality, have become a major adverse side-effect with severe negative effects on the health of human beings and on sustainable socioeconomic development. The particulate matter generated in urban environments is believed to be a leading killer of humans, as it contains many hazardous materials such as heavy metals, acid oxides, organic matter, bacteria, and viruses. Among these particulates, the adverse effects of the size classes smaller than $2.5 \mu \mathrm{m}$ $\left(\mathrm{PM}_{2.5}\right)$ and $10.0 \mu \mathrm{m}\left(\mathrm{PM}_{10}\right)$ have been studied in detail (Alleman et al. 2010; Dongarrà et al. 2010; Lim et al. 2010; Muránszky et al. 2011); however, particulates with a larger grain size, and particularly the particulates called "foliage dust" because they are frequently deposited on the surface of leaves, have received much less attention around the world.

Field observations have confirmed that foliage dust provides strong clues to the characteristics of the urban atmospheric environment (Coe and Lindberg 1987; Freer-Smith et al. 1997; Bargagli 1998; Wang et al. 2009). Therefore, the heavy metal concentration in foliage dust has been used as an 
indicator and pollution monitor of the urban atmospheric environment (Tomašević et al. 2005; Simon et al. 2011). For example, Simon et al. (2011) reported that the heavy metal concentrations in foliage dust were significantly higher in an urban area of Vienna, Austria, than in a rural area of the city, and the urbanization significantly increased the heavy metal concentrations in foliage dust. Maher et al. (2008) analyzed leaves at different heights in Norwich (UK) and found that particulate $\mathrm{Pb}$ concentrations were highest at $\sim 0.3 \mathrm{~m}$ (i.e., about the height of a small child) and at $1.5-2.0 \mathrm{~m}$ (head height for an adult) above ground level. Moreover, Tomašević et al. (2005) studied the characteristics of heavy metal particles deposited on tree leaves in the urban area of Belgrade (Serbia and Montenegro), and found that the deposited particles were mainly originated from vehicle traffic and from resuspended particulate matter. In the urban area of Hangzhou (China), Lu et al. (2008) noted that the dust on tree leaves contained high concentrations of $\mathrm{Pb}$ (a mean of $150.9 \mathrm{mg} \mathrm{kg}^{-1}$ ), $\mathrm{Zn}$ $\left(535.9 \mathrm{mg} \mathrm{kg}^{-1}\right), \mathrm{Cu}\left(63.7 \mathrm{mg} \mathrm{kg}^{-1}\right)$, and $\mathrm{Cd}(2.62 \mathrm{mg}$ $\mathrm{kg}^{-1}$ ). Qiu et al. (2009) studied the foliage dust on urban leaf surfaces in Huizhou, southern China, and found that the heavy metal contents were high, particularly for $\mathrm{Pb}$ and $\mathrm{Cd}$, which ranged from 434.0 to $512.0 \mathrm{mg} \mathrm{kg}^{-1}$ and 6.2 to $12.8 \mathrm{mg} \mathrm{kg}^{-1}$, respectively.

Guangzhou, the capital of Guangdong Province and part of the Pearl River Delta region, is one of China's largest industrial centers and fastest expanding cities (Duzgoren-Aydin 2007). Its rapid economic development has brought great prosperity to the region, but has also given rise to a wide variety of environmental problems, particularly in terms of traffic jams and air pollution. When Guangzhou was awarded the right to host the 2010 Asian Games, the local environmental protection authority invested 600 million RMB to improve the city's air quality. The effects of air pollution are currently a serious concern to the local government, to citizens, and to tourists. Moreover, because of the city's well-developed traffic system, dozens of roads criss-cross the urban region. To help pedestrians cross these busy roads conveniently and safely, hundreds of pedestrian bridges have been installed. The pedestrian bridges are located at a height of about $5 \mathrm{~m}$, and Bougainvillea spectabilisWilld has been planted alongside the bridges. As a result, this vegetation can be used as a natural collector of atmospheric particulates.

The aim of the present study was to determine the levels of seven heavy metals $(\mathrm{Pb}, \mathrm{Zn}, \mathrm{Cu}, \mathrm{Ni}, \mathrm{Co}, \mathrm{Cr}$, and $\mathrm{V})$ in the urban atmosphere of Guangzhou using dust deposited on the leaf surfaces as a proxy for these levels. The results can provide a baseline for use in future environmental impact assessments and to guide pollution mitigation targets.

\section{Materials and methods}

Study area

Guangzhou is adjacent to the estuary of the Pearl River, in the southern part of China. Situated in a subtropical monsoon climate zone, it has a mild climate with a long summer and a short winter, with distinct wet and dry seasons. The mean annual temperature ranges from 20.6 to $22.5^{\circ} \mathrm{C}$, and the annual total rainfall averages approximately $2,388 \mathrm{~mm}$. The winters are dry and cold, with a prevailing north wind; the summer is wet and hot, with a prevailing south wind.

The study area extends from $22^{\circ} 26^{\prime}$ to $23^{\circ} 56^{\prime} \mathrm{N}$ and from $112^{\circ} 57^{\prime}$ to $114^{\circ} 03^{\prime} \mathrm{E}$, covering an area of more than $3,800 \mathrm{~km}^{2}$. To support a population of more than 10.33 million, the city has a well-developed transport system that includes two highways, four major north-south roads, eight major east-west roads, and hundreds of minor roads. At the end of 2009, more than 1.34 million vehicles were in use in the city. Guangzhou's industry is scattered in and around the urban area, and the goods and services sector dominates the economy (63\% of the total economic output).

\section{Sampling}

Previous studies have shown that leaves trap particulate matter only temporarily. When precipitation is greater than $5 \mathrm{~mm}$ or the wind speed in greater than $17 \mathrm{~m} / \mathrm{s}$, these particulates are typically removed from the leaves (Zhao et al. 2002). Therefore, all the samples were collected in the present study from September to October in 2009, during the dry winter months. During this period, the wind speed was typically much lower than $17 \mathrm{~m} / \mathrm{s}$, and only a few precipitation events were recorded. Therefore, this was a suitable period for sample collection.

A total of 36 pedestrian bridges were chosen at different locations within the urban area of Guangzhou (Fig. 1). To obtain samples, 100-150 leaves were picked from the top part of braches above the sidewalk on each side of bridge. Every sample consisted of about $200 \mathrm{~g}$ of leaves. The leaves were stored in glass petri dishes during transport to prevent the loss of dust. The leaves were oven-dried at $35{ }^{\circ} \mathrm{C}$ for 3 days, and then weighed. The dust on the leaf surface was collected using a plastic brush. A different brush was used for the leaves collected at each location. Samples from each site were bulked to produce a single composite sample before analysis.

Heavy metal analysis

Each ca $0.02 \mathrm{~g}$ dried dust was transferred into a Teflon beaker $(50 \mathrm{~mL})$ and then was digested using a mixture of 
Fig. 1 The locations of the sites where foliage dust was sampled in Guangzhou

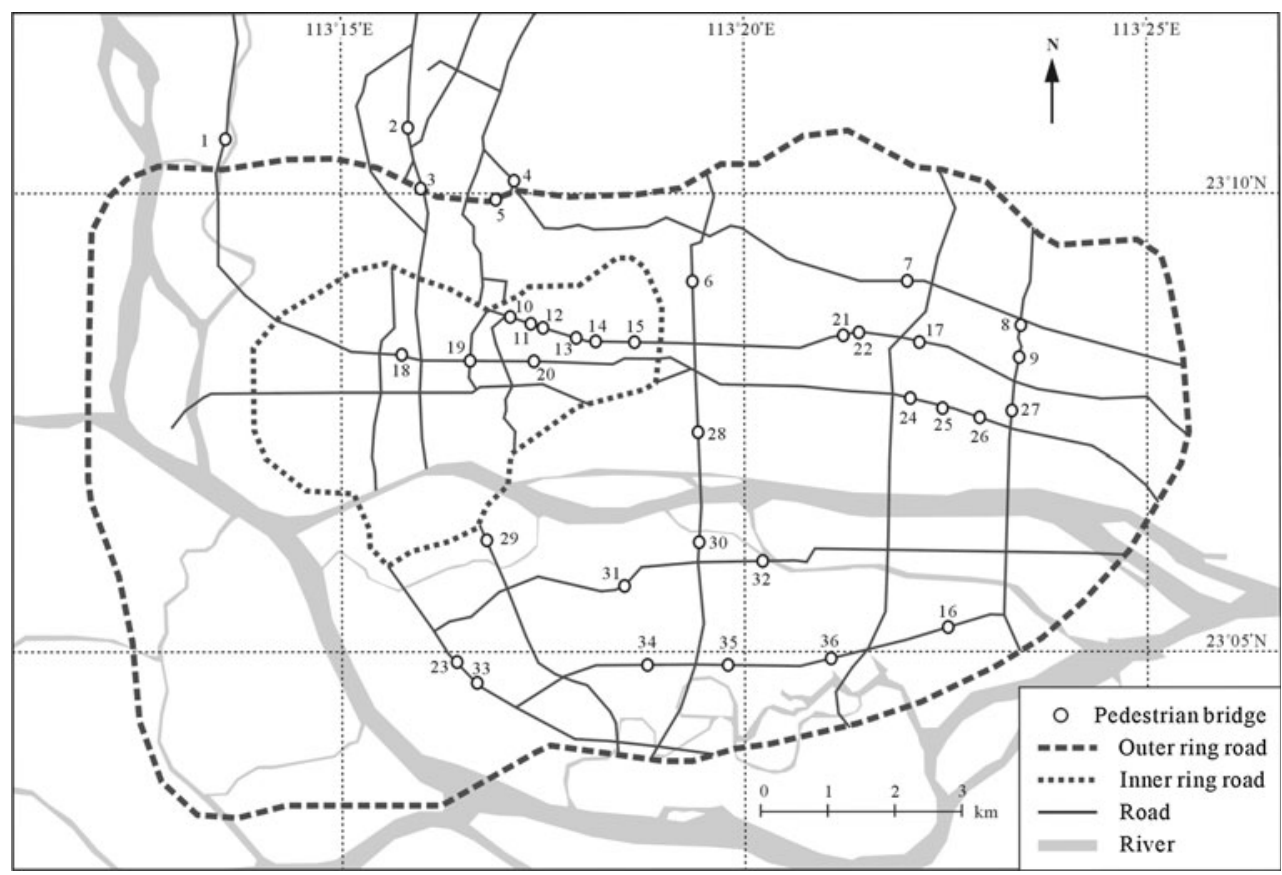

strong acids composed of $1 \mathrm{~mL} \mathrm{HNO}_{3}(15.9 \mathrm{M}), 3 \mathrm{~mL} \mathrm{HCl}$ $(12.1 \mathrm{M}), 4 \mathrm{~mL} \mathrm{HF}(28.9 \mathrm{M})$, and $2 \mathrm{~mL} \mathrm{HClO}_{4}(11.7 \mathrm{M})$. The sample was heated on a temperature-programmed hot plate for $2 \mathrm{~h}$ at $120^{\circ} \mathrm{C}$ with the beaker covered, and then was heated to $160{ }^{\circ} \mathrm{C}$ for $10 \mathrm{~h}$, until all of the samples were digested. The beaker was then uncovered and the sample was heated to $180^{\circ} \mathrm{C}$ until completely dry. Afterwards, the residues were extracted with $10 \mathrm{ml} 0.8 \mathrm{M}$ high-purity $\mathrm{HNO}_{3}$ and kept in a refrigerator prior to analysis. The heavy metal concentrations of the foliage dusts were determined using an inductively coupled plasma-optical emission spectrometer (ULTIMA 2, manufactured by HORIBA Jobin-Yvon Company, Pairs, France) at Xi'an Institute of Earth Environment, Chinese Academy of Sciences (CSA). Blanks, quality control standard samples(ESS-3, environmental soil) and duplicated samples were simultaneously performed as quality control, with standard reference materials (ESS-3) giving recoveries more than $85 \%$ for all these trace elements according to certified values. In the measurement, the LODs of refered heavy metal are as follows: $\mathrm{Co}-0.76, \mathrm{Cr}-0.28, \mathrm{Cu}-0.09$, Ni$1.07, \mathrm{~Pb}-10.3, \mathrm{~V}-0.55$ and $\mathrm{Zn}-0.16 \mu \mathrm{g} / \mathrm{L}$. On average, the analytical precision, measured as relative standard deviation (RSD), was routinely between 3 and $5 \%$ for all analyzed elements.

\section{Statistical analyses}

The concentrations were analyzed using version 19.0 of the SPSS software for Windows (SPSS Inc., Chicago, IL, USA). Correlation matrices were used to identify the relationships among the seven elements (Han et al. 2006;
Lu et al. 2010). In this analysis, Pearson's product-moment correlation coefficient $(r)$ was used. Principal-components analysis (PCA) were also used to group the heavy metals and infer their hypothetical source (Han et al. 2006; Tokalıoğlu and Kartal 2006; Meza-Figueroa et al. 2007). The components of the PCA were transformed using a varimax rotation with Kaiser normalization after the analysis. Cluster analysis was applied to identify different geochemical groups by clustering the samples with a similar heavy metal content (Han et al. 2006; Lu et al. 2010). Cluster analysis was performed according to Ward's method (Han et al. 2006). The results were displayed as a dendrogram created using hierarchical clustering, and values of the distances between clusters (the squared Euclidean distance) were presented.

\section{Results and discussion}

\section{Heavy metal concentrations}

Table 1 summarizes the heavy metal concentrations in the urban dust collected in Guangzhou, and presents the mean values for Chinese soils (CNEMC 1990) and local soils in the Pearl River Delta (Wong et al. 2002), which are used as the reference values for acceptable levels in China. The mean concentrations were $1,024 \mathrm{mg} \mathrm{kg}^{-1}$ for $\mathrm{Zn}$, $233 \mathrm{mg} \mathrm{kg}^{-1}$ for $\mathrm{Pb}, 203 \mathrm{mg} \mathrm{kg}^{-1}$ for $\mathrm{Cu}, 118 \mathrm{mg} \mathrm{kg}^{-1}$ for $\mathrm{Cr}, 41.9 \mathrm{mg} \mathrm{kg}^{-1}$ for $\mathrm{V}, 41.4 \mathrm{mg} \mathrm{kg}^{-1}$ for $\mathrm{Ni}$, and $11.3 \mathrm{mg} \mathrm{kg}^{-1}$ for Co. Data as presented exhibit a considerable variations between the maximum and minimum values: $\mathrm{Zn}\left(2,058-355 \mathrm{mg} \mathrm{kg}^{-1)}, \mathrm{Pb}\left(504-125 \mathrm{mg} \mathrm{kg}^{-1)}\right.\right.$, 
Table 1 Heavy metal concentrations in the foliage dust collected in Guangzhou ( $\left.\mathrm{mg} \mathrm{kg}^{-1}\right)$

\begin{tabular}{|c|c|c|c|c|c|c|c|}
\hline \multicolumn{8}{|c|}{ Concentration and related statistical parameters } \\
\hline Element & $\mathrm{Zn}$ & $\mathrm{Pb}$ & $\mathrm{Cu}$ & $\mathrm{Cr}$ & $\mathrm{V}$ & $\mathrm{Ni}$ & Co \\
\hline 1 & 1229 & 317 & 203 & 111 & 53.0 & 39.9 & 10.3 \\
\hline 2 & 1198 & 254 & 210 & 181 & 38.6 & 48.3 & 11.7 \\
\hline 3 & 1738 & 287 & 351 & 100 & 44.1 & 59.2 & 20.4 \\
\hline 4 & 2058 & 239 & 469 & 105 & 32.7 & 61.0 & 11.6 \\
\hline 5 & 1747 & 215 & 272 & 101 & 35.2 & 44.3 & 12.5 \\
\hline 6 & 957 & 225 & 199 & 111 & 46.5 & 32.5 & 10.2 \\
\hline 7 & 1345 & 397 & 222 & 175 & 48.5 & 38.7 & 13.0 \\
\hline 8 & 987 & 241 & 195 & 116 & 45.1 & 29.3 & 10.7 \\
\hline 9 & 1365 & 292 & 204 & 161 & 35.6 & 33.0 & 11.8 \\
\hline 10 & 1295 & 217 & 234 & 109 & 33.6 & 54.8 & 9.7 \\
\hline 11 & 978 & 220 & 210 & 97.3 & 50.9 & 49.0 & 10.7 \\
\hline 12 & 962 & 196 & 236 & 98.1 & 48.0 & 39.9 & 11.5 \\
\hline 13 & 971 & 184 & 227 & 108 & 57.1 & 44.8 & 10.7 \\
\hline 14 & 902 & 190 & 213 & 100 & 36.3 & 37.4 & 9.9 \\
\hline 15 & 830 & 146 & 183 & 93.1 & 36.1 & 50.0 & 9.6 \\
\hline 16 & 897 & 333 & 180 & 128 & 55.8 & 42.7 & 13.7 \\
\hline 17 & 420 & 134 & 87.9 & 63.2 & 34.3 & 26.4 & 9.1 \\
\hline 18 & 1047 & 198 & 260 & 104 & 62.9 & 38.2 & 10.1 \\
\hline 19 & 801 & 182 & 185 & 101 & 30.5 & 26.6 & 8.3 \\
\hline 20 & 1146 & 237 & 229 & 114 & 35.3 & 58.8 & 10.8 \\
\hline 21 & 467 & 221 & 90.6 & 72.9 & 32.5 & 24.1 & 10.0 \\
\hline 22 & 355 & 125 & 74.8 & 43.1 & 36.4 & 19.6 & 9.7 \\
\hline 23 & 975 & 198 & 146 & 97.3 & 56.9 & 36.2 & 10.0 \\
\hline 24 & 974 & 216 & 198 & 138 & 35.5 & 61.6 & 11.8 \\
\hline 25 & 882 & 199 & 168 & 156 & 33.0 & 55.5 & 11.1 \\
\hline 26 & 947 & 207 & 202 & 162 & 39.9 & 40.3 & 12.3 \\
\hline 27 & 1246 & 312 & 186 & 132 & 43.7 & 33.9 & 11.3 \\
\hline 28 & 1070 & 215 & 246 & 266 & 49.5 & 52.6 & 14.9 \\
\hline 29 & 1445 & 504 & 240 & 154 & 48.5 & 65.5 & 11.1 \\
\hline 30 & 709 & 176 & 152 & 89.5 & 39.5 & 31.7 & 11.1 \\
\hline 31 & 830 & 178 & 206 & 92.9 & 28.2 & 37.7 & 9.0 \\
\hline 32 & 934 & 200 & 200 & 97.2 & 36.9 & 40.8 & 10.5 \\
\hline 33 & 666 & 173 & 108 & 74.4 & 36.3 & 26.4 & 10.1 \\
\hline 34 & 1051 & 325 & 191 & 118 & 38.2 & 33.0 & 11.6 \\
\hline 35 & 835 & 219 & 192 & 168 & 40.1 & 44.0 & 12.4 \\
\hline 36 & 591 & 218 & 122 & 96.0 & 52.6 & 32.5 & 12.6 \\
\hline Minimum & 355 & 125 & 74.8 & 43.1 & 28.2 & 19.6 & 8.3 \\
\hline Maximum & 2058 & 504 & 469 & 266 & 62.9 & 65.5 & 20.4 \\
\hline Mean & 1024 & 233 & 203 & 118 & 41.9 & 41.4 & 11.3 \\
\hline SD & 358 & 74.4 & 70.6 & 40.5 & 8.8 & 11.7 & 2.1 \\
\hline CV (\%) & 35.0 & 31.9 & 34.9 & 34.4 & 20.9 & 28.4 & 18.4 \\
\hline $\begin{array}{l}\text { Reference value } \\
\text { CNEMC (1990) }\end{array}$ & 74.2 & 26.0 & 22.6 & 61.0 & 82.4 & 26.9 & 12.7 \\
\hline $\begin{array}{l}\text { Reference value } \\
\text { Wong et al. (2002) }\end{array}$ & 50.7 & 29.9 & 14.7 & 51.8 & $\mathrm{Nd}$ & 16.5 & 7.1 \\
\hline $\begin{array}{l}\text { Ratio (mean/ } \\
\text { reference value) }\end{array}$ & 13.8 & 9.0 & 9.0 & 1.9 & 0.5 & 1.5 & 0.9 \\
\hline
\end{tabular}

Table 1 continued

Concentration and related statistical parameters

\begin{tabular}{llllllll}
\hline Element & $\mathrm{Zn}$ & $\mathrm{Pb}$ & $\mathrm{Cu}$ & $\mathrm{Cr}$ & $\mathrm{V}$ & $\mathrm{Ni}$ & $\mathrm{Co}$ \\
\hline $\begin{array}{c}\text { Ratio (mean/ } \\
\text { reference value) }\end{array}$ & 20.2 & 7.8 & 13.8 & 2.3 & $\mathrm{Nd}$ & 2.5 & 1.6 \\
\hline
\end{tabular}

$\mathrm{CV}[\mathrm{SD} / \mathrm{mean}] \times 100 \%, \mathrm{Nd}$ no data is available

Table 2 The Pearson's correlation coefficient $(r)$ matrix for the relationships among the concentrations of the seven heavy metals

\begin{tabular}{llllllll}
\hline & $\mathrm{Co}$ & $\mathrm{Cr}$ & $\mathrm{Cu}$ & $\mathrm{Ni}$ & $\mathrm{Pb}$ & $\mathrm{V}$ & $\mathrm{Zn}$ \\
\hline $\mathrm{Co}$ & & 0.01 & 0.01 & 0.01 & 0.03 & 0.15 & $<0.01$ \\
$\mathrm{Cr}$ & $0.41^{* *}$ & & 0.11 & 0.01 & 0.01 & 0.32 & 0.05 \\
$\mathrm{Cu}$ & $0.44^{* *}$ & 0.27 & & $<0.01$ & 0.09 & 0.73 & $<0.01$ \\
$\mathrm{Ni}$ & $0.41^{* *}$ & $0.43^{* *}$ & $0.67^{* *}$ & & 0.04 & 0.85 & $<0.01$ \\
$\mathrm{~Pb}$ & $0.36^{*}$ & $0.43^{* *}$ & 0.29 & $0.34^{*}$ & & 0.07 & $<0.01$ \\
$\mathrm{~V}$ & 0.24 & 0.17 & 0.06 & 0.03 & 0.30 & & 0.74 \\
$\mathrm{Zn}$ & $0.47^{* *}$ & $0.33^{*}$ & $0.88^{* *}$ & $0.63^{* *}$ & $0.53^{* *}$ & 0.06 &
\end{tabular}

The bottom left of the table presents the correlation coefficients; the top right represents the significance level $(*<0.05 ; * *<0.01)$

$\mathrm{Cu} \quad\left(469-74.8 \mathrm{mg} \mathrm{kg}^{-1)}, \quad \mathrm{Cr} \quad\left(266-43.1 \mathrm{mg} \mathrm{kg}^{-1)}, \mathrm{V}\right.\right.$ $\left(62.9-28.2 \mathrm{mg} \mathrm{kg}^{-1)}\right.$, Ni $\left(65.5-19.6 \mathrm{mg} \mathrm{kg}^{-1)}\right.$ and $\mathrm{Co}$ (20.4-8.3 $\mathrm{mg} \mathrm{kg}^{-1}$ ). Compared with the reference values of Chinese soils (Table 1), the mean concentrations of $\mathrm{Zn}$, $\mathrm{Pb}$, and $\mathrm{Cu}$ in the samples are conspicuously higher by factors of 13.8, 9.0, and 9.0. The mean concentrations of $\mathrm{Cr}$ and $\mathrm{Ni}$ are also slightly higher by factors of 1.9 and 1.5 , respectively. In the meantime, the mean concentration of Co is comparable with the reference value of Chinese soil, while that of $\mathrm{V}$ is considerably low.

Correlation analysis

Table 2 summarizes the Pearson's correlation coefficients $(r)$ for the heavy metals, where all element-element pairs are positively correlated. The statistically significant pairs $(P<0.01)$ are outlined. $\mathrm{Zn}$ is significantly correlated with $\mathrm{Cu}(r=0.88), \mathrm{Ni}(r=0.63), \mathrm{Pb}(r=0.53)$ and $\mathrm{Co}$ ( $r=0.47) . \mathrm{Pb}$ is correlated with $\mathrm{Cr}(r=0.43)$, while $\mathrm{Ni}$ is correlated with $\mathrm{Cu}(r=0.67), \mathrm{Cr}(r=0.43)$ and $\mathrm{Co}$ $(r=0.41)$. Both $\mathrm{Cu}$ and $\mathrm{Cr}$ are correlated with $\mathrm{Co}$ with $r$ values of 0.44 and 0.41 , respectively. On the contrary, $\mathrm{V}$ exhibits weak $(r \leq 0.3)$ and nonsignificant correlations with all other metals.

Principal-components analysis

Because of the complexity of the correlation results, it was necessary to perform additional analysis to group the heavy metals and infer their sources. PCA has been successfully 
Table 3 Results of the PCA for the heavy metal concentrations of the foliage dusts collected in Guangzhou after varimax rotation with Kaiser normalization

\begin{tabular}{lrrrl}
\hline Element & \multicolumn{3}{c}{ Principal component } & \multirow{2}{*}{ Communalities } \\
\cline { 2 - 4 } & \multicolumn{1}{c}{ 1 } & \multicolumn{2}{l}{3} & \\
\hline $\mathrm{Co}$ & 0.45 & 0.46 & 0.32 & 0.52 \\
$\mathrm{Cr}$ & 0.14 & 0.93 & 0.03 & 0.89 \\
$\mathrm{Cu}$ & 0.95 & 0.07 & 0.05 & 0.92 \\
$\mathrm{Ni}$ & 0.73 & 0.39 & -0.08 & 0.70 \\
$\mathrm{~Pb}$ & 0.31 & 0.54 & 0.44 & 0.58 \\
$\mathrm{~V}$ & -0.03 & 0.08 & 0.94 & 0.90 \\
$\mathrm{Zn}$ & 0.92 & 0.20 & 0.11 & 0.89 \\
Initial eigenvalues & 3.39 & 1.22 & 0.77 & \\
Variance (\%) & 48.44 & 17.48 & 11.05 & \\
Cumulative variance (\%) & 48.44 & 65.92 & 76.97 & \\
\hline
\end{tabular}

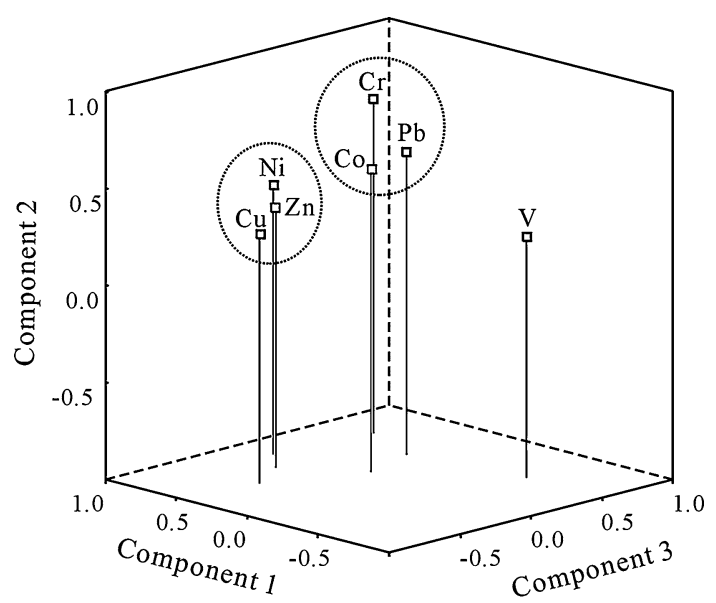

Fig. 2 PCA loadings for the three principal components from the PCA (PC1 vs. PC2 vs. PC3) for the seven heavy metal elements. Details are shown in Table 3

used to identify the sources of pollutants (Han et al. 2006; Tokalığlu and Kartal 2006; Meza-Figueroa et al. 2007; Lu et al. 2010). By extracting the eigenvalues and eigenvectors from the correlation matrix, it was able to determine the number of significant principal components and the percentage of the total variance they explained (Table 3). Three statistically significant components that together explained about $77 \%$ of the total variance were obtained. The first two eigenvalues (both $>1$ ) explained $\approx 66 \%$ of the total variance, indicating that they are the most important factors. The first factor explained $48.4 \%$ of the total variance and had the greatest weights for $\mathrm{Cu}, \mathrm{Zn}$, and $\mathrm{Ni}$. Factor two had the greatest weights for $\mathrm{Cr}, \mathrm{Pb}$, and $\mathrm{Co}$, and accounted for $17.5 \%$ of the total variance. The third factor (eigenvalue $=0.77$ ) explained about $11 \%$ of the total variance, and had the strongest weight (0.94) for $\mathrm{V}$. Figure 2 presents a 3-D plot of the three PCA loadings,

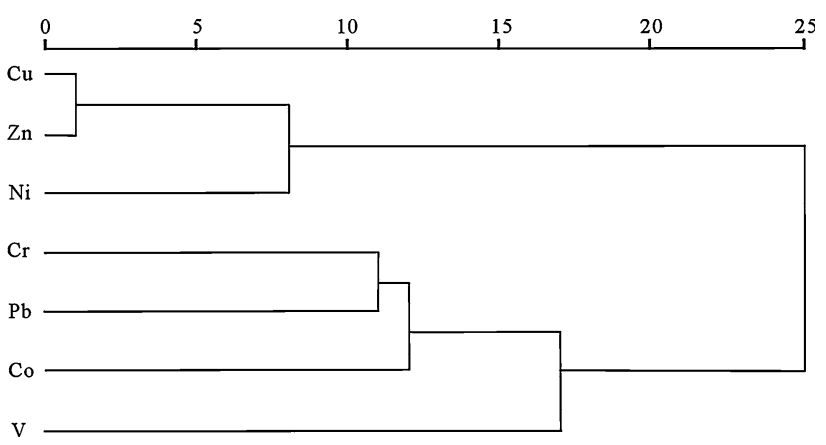

Fig. 3 Hierarchical dendrogram for the seven elements obtained using Ward's clustering method

which clearly reveals these relationships among the seven heavy metals.

\section{Cluster analysis}

Before cluster analysis, the values were standardized using $z$-scores; then the Euclidean distances among the values for the heavy metals were calculated. Finally, hierarchical clustering were performed using Ward's method. Figure 3 shows the results as a dendrogram. The cluster has three overall subgroups: the first contains $\mathrm{Cu}, \mathrm{Zn}$, and $\mathrm{Ni}$; the second contains $\mathrm{Cr}, \mathrm{Pb}$, and $\mathrm{Co}$; and the third only includes $\mathrm{V}$. The clustering confirmed the results of the PCA.

\section{Source identification}

The use of multivariate statistical techniques has proven to be an effective tool for extracting information on heavy metals in urban dust (Han et al. 2006; Tokalığlu and Kartal 2006; Lu et al. 2010), such as the Principal component analysis (PCA). PCA has been widely used to identify the sources of pollutants and can effectively reduce the number of variables and thereby facilitate analysis of the relationships among the observed variables (Tokalıoğlu and Kartal 2006). In general, significant correlations between pairs of heavy metals suggest a common or combined origin, whereas weak correlations indicate different origins.

Table 3 and Figs. 2 and 3 suggest that the seven heavy metals could be classified into the same three categories: Group $1(\mathrm{Zn}, \mathrm{Cu}$, and $\mathrm{Ni})$, Group $2(\mathrm{~Pb}, \mathrm{Cr}$, and $\mathrm{Co})$, and Group $3(\mathrm{~V})$. These results indicated that $\mathrm{Zn}, \mathrm{Cu}$, and $\mathrm{Ni}$ probably have a mixed anthropogenic sources-including combustion processes and vehicles. Generally speaking, $\mathrm{Zn}, \mathrm{Cu}$ and $\mathrm{Ni}$ are associated with combustion processes, for example, the combustion of coal usually emits high amounts of all three metals (Yang and Cheng 2002; Wang et al. 2008), the burning of other fossil fuels such as oil produces emissions that contain large amounts of $\mathrm{Ni}$ and 
$\mathrm{Cu}$ (Yang and Cheng 2002), and waste incineration and metal smelting produce emissions containing high levels of $\mathrm{Ni}$ and $\mathrm{Cu}$ (Yang and Cheng 2002). Compared with the mean values in Chinese soils (Table 1), the mean concentrations of $\mathrm{Zn}$ and $\mathrm{Cu}$ are conspicuously higher, while $\mathrm{Ni}$ is slightly enriched. In this study, all the samples were collected at a height of 5-6 $\mathrm{m}$ above major roads surrounded by high-rise residential and commercial buildings, and there was no incineration of municipal refuse and few factories used to refine molten metal upwind of these sites. On this basis, it could hypothesize that the Group 1 metals were also mainly derived from vehicle exhaust emissions, as well as lubricating oil and grease. Because $\mathrm{Zn}, \mathrm{Cu}$, and $\mathrm{Ni}$ are widely used in tires and vehicle body parts, the higher wear rates that result from the high temperatures of subtropical Guangzhou may contribute to high $\mathrm{Zn}, \mathrm{Cu}$, and $\mathrm{Ni}$ contents in the foliage dust (Duzgoren-Aydin et al. 2006). The exhaust gases released from the restaurant industry and from residential areas surrounding the study area would have been another important source, since the local government has promoted the use of liquefied petroleum gas (LPG) for heating and cooking since 2003, largely eliminating the "black smoke" phenomenon that resulted from using coal for these purposes. However, vehicle exhaust emissions may still contain high contents of $\mathrm{Zn}$ and $\mathrm{Cu}$. In addition, the waste gases emitted by families during cooking must not be neglected during management of the urban air environment, because coal remains a popular fuel due to its low cost.

The metals in Group $2(\mathrm{~Pb}, \mathrm{Cr}$, and $\mathrm{Co}$ ) were significantly correlated. The mean concentration of the Co was close to the Chinese soil reference value (Table 1), so its source is likely to be mainly from local surface soils. The mean concentration of the $\mathrm{Cr}$ was much higher than the mean value in Chinese soils, and its source appears to be associated with the chrome plating of some vehicle parts (Christoforidis and Stamatis 2009). The mean concentration of $\mathrm{Pb}$ was much higher than the background value in Chinese soil (Table 1). Many studies have confirmed that $\mathrm{Pb}$ is mainly produced by vehicle exhaust emissions, and it is a signature element for the pollution caused by traffic (Yang and Cheng 2002; Han et al. 2006; Lu et al. 2010). In a word, the metals in Group 2 mainly come from vehicle sources, combined with soil sources as well for Co.

Group 3 includes only V, which showed no significant correlation with any other element, indicating that it has a different source. The concentration of $\mathrm{V}$ was relatively consistent (see the low standard deviation and $\mathrm{CV}$ value in Table 1) despite significant differences in their surrounding environmental conditions. This suggests that $\mathrm{V}$ is likely derived from natural sources (Duzgoren-Aydin et al. 2006).

\section{Conclusions}

The concentrations and sources of the heavy metals $\mathrm{Zn}$, $\mathrm{Pb}, \mathrm{Cu}, \mathrm{Cr}, \mathrm{Ni}, \mathrm{V}$, and $\mathrm{Co}$ in foliage dusts collected near pedestrian bridges in Guangzhou have been studied in this work. The accumulation of these metals in the foliage dust is obvious, with mean concentrations significantly higher than the background values in Chinese soil for all metals except $\mathrm{V}$ and Co. Based on multivariate statistical analyses, the heavy metals were classified into three main groups according to their sources: (1) $\mathrm{Zn}, \mathrm{Cu}$, and $\mathrm{Ni}$ appear to have resulted from combustion processes and vehicles; (2) $\mathrm{Pb}, \mathrm{Cr}$, and $\mathrm{Co}$ appear to be produced by vehicle traffic, combined with soil sources; and (3) V, which was not significantly correlated with any other metal, probably had a natural source, possibly local soils.

Acknowledgments This study was supported by the Research Fund for the Doctoral Program of Higher Education of China (20094407120004), the State Key Laboratory of Loess and Quaternary Geology, Institute of Earth Environment, Chinese Academy of Sciences (SKLLQG1013), and the Open Project from MOE Engineering Center of Desertification and Blown-sand Control, Beijing Normal University (2011E-04) and the Provincial University Student Innovation Program of South China Normal University. We thank Dr. Song Shaohua and Mr. Xiong Xiaohu for their assistance in the heavy metal analysis. We also gratefully acknowledge two anonymous reviewers whose comments greatly helped this manuscript become more clear, thorough and persuasive.

Open Access This article is distributed under the terms of the Creative Commons Attribution License which permits any use, distribution, and reproduction in any medium, provided the original author(s) and the source are credited.

\section{References}

Alleman LY, Lamaison L, Perdrix E, Robache A, Galloo JC (2010) $\mathrm{PM}_{10}$ metal concentrations and source identification using positive matrix factorization and wind sectoring in a French industrial zone. Atmos Res 96:612-625

Bargagli R (1998) Trace Elements in Terrestrial Plants: An Ecophysiological Approach to Biomonitoring and Biorecovery. Springer-Verlag, Berlin

Christoforidis A, Stamatis N (2009) Heavy metal contamination in street dust and roadside soil along the major national road in Kavala's region, Greece. Geoderma 151:257-263

CNEMC (China national environmental monitoring centre) (1990) The background values of Chinese soils. Environmental Science Press of China, Beijing (in Chinese)

Coe JM, Lindberg SE (1987) The morphology and size distribution of atmospheric particles deposited on foliage and inert surfaces. J Air Pollut Control Assoc 37:237-243

Dongarrà G, Manno E, Varrica D, Lombardo M, Vultaggio M (2010) Study on ambient concentrations of $\mathrm{PM}_{10}, \mathrm{PM}_{10-2.5}, \mathrm{PM}_{2.5}$ and gaseous pollutants. Trace elements and chemical speciation of atmospheric particulates. Atmos Environ 44:5244-5257 
Duzgoren-Aydin NS (2007) Sources and characteristics of lead pollution in the urban environment of Guangzhou. Sci Total Environ 385:182-195

Duzgoren-Aydin NS, Wong CSC, Aydin A, Song Z, You M, Li XD (2006) Heavy metal contamination and distribution in the urban environment of Guangzhou, SE China. Environ Geochem Health 28:375-391

Freer-Smith PH, Holloway S, Goodman A (1997) The uptake of particulates by an urban woodland: site description and particulate composition. Environ Pollut 95:27-35

Han YM, Du PX, Cao JJ, Posmentier ES (2006) Multivariate analysis of heavy metal contamination in urban dusts of Xi' an, Central China. Sci Total Environ 355:176-186

Lim JM, Lee JH, Moon JH, Chung YS, Kim KH (2010) Airborne $\mathrm{PM}_{10}$ and metals from multifarious sources in an industrial complex area. Atmos Res 96:53-64

Lu SG, Zheng YW, Bai SQ (2008) A HRTEM/EDX approach to identification of the source of dust particles on urban tree leaves. Atmos Environ 42:6431-6441

Lu XW, Wang LJ, Li LY, Lei K, Huang L, Kang D (2010) Multivariate statistical analysis of heavy metals in street dust of Baoji, NW China. J Hazard Mater 173:744-749

Maher BA, Moore C, Matzka J (2008) Spatial variation in vehiclederived metal pollution identified by magnetic and elemental analysis of roadside tree leaves. Atmos Environ 42:364-373

Meza-Figueroa D, O-Villanueva MD, Parra MLD (2007) Heavy metal distribution in dust from elementary schools in Hermosillo, Sonora, México. Atmos Environ 41:276-288

Muránszky G, Óvári M, Virág I, Csiba P, Dobai R, Záray G (2011) Chemical characterization of $\mathrm{PM}_{10}$ fractions of urban aerosol. Microchem J 44:1-10
Qiu Y, Guan DS, Song WW, Huang KY (2009) Capture of heavy metals and sulfur by foliar dust in urban Huizhou, Guangdong Province, China. Chemosphere 75:447-452

Simon E, Braun M, Vidic A, Bogyó D, Fábián I, Tóthmérész B (2011) Air pollution assessment based on elemental concentration of leaves tissue and foliage dust along an urbanization gradient in Vienna. Environ Pollut 159:1229-1233

Tokalığlu Ş, Kartal Ş (2006) Multivariate analysis of the data and speciation of heavy metals in street dust samples from the organized industrial district in Kayseri (Turkey). Atmos Environ 16:2797-2805

Tomašević M, Vukmirović Z, Rajšić S, Tasić M, Stevanović B (2005) Characterization of trace metal particles deposited on some deciduous tree leaves in an urban area. Chemosphere 61:753-760

Wang BG, Yang JH, Zhou Y, Feng ZC, Liu HX (2008) The emission characteristics of metal elements in urban motor vehicles exhaust of Guangzhou City. China Environ Sci 28:389-394 (in Chinese)

Wang J, Chen ZL, Sun XJ, Shi GT, Xu SY, Wang DQ, Wang L (2009) Quantitative spatial characteristics and environmental risk of toxic heavy metals in urban dusts of Shanghai, China. Environ Earth Sci 59:645-654

Wong SC, Li XD, Zhang G, Qi SH, Min YS (2002) Heavy metals in agricultural soils of the Pearl River Delta, South China. Environ Pollut 119:33-44

Yang LP, Cheng FH (2002) Study on the source apportionment of atmospheric dust pollutants in Lanzhou. Acta Sci Circumst 22:499-502 (in Chinese)

Zhao Y, Li SR, Yan ZP (2002) The Effect of Greenland on absorbed dust and its assessment method. J Huazhong Agr U 21:582-586 (in Chinese) 